\title{
DOES COUNTRY CREDIT RATING AFFECT CURRENT DEFICIT ACCOUNT: THE CASE OF TURKEY (1992-2014)
}

\section{Ahmet Gulmez, Furkan Besel, Fatih Yardimcioglu}

(1) Department of Economics, Sakarya University, 54,100, Turkey (2) Department of Public Finance, Sakarya University, 54,100, Turkey (3)Department of Public Finance, Sakarya University, 54,100, Turkey

\author{
Ahmet Gulmez \\ Department of Economics, Sakarya University \\ 54,100, Turkey \\ Article info \\ Paper category: Original Scientific Paper \\ Received: 18.5 .2017 . \\ Accepted: 20.6.2017. \\ JEL classification: $\mathrm{E}_{51}, \mathrm{H} 62$
}




\begin{abstract}
In this study the presence and direction of the relationship between the current account deficit and credit rating index for Turkey has been tested using Gregory-Hansen co-integration test, which considers structural breaks and Toda-Yamamoto causality analysis for the period of 1992-2014. Based on the results of empirical applications, it has been concluded that both series are not stable and there is a long-term relationship between the variables. As a result of the Toda-Yamamoto method based on the Granger causality analysis, it has been determined that there is a one-way causal relationship between the variables from current account deficit towards credit rating index.
\end{abstract}

\title{
Keywords:
}

Account deficit; Credit rating; Gregory-Hansen co-integration test; Toda-Yamamoto causality analysis 


\section{INTRODUCTION}

Despite the first appearance of the concept of rating in literature in 1837 , in the 1980 s it had become more prominent with the spread of global liberalization movements, including those in Turkey. Rating is a classification system that is used to estimate whether an organization or individual discharges its/their financial obligations on time and on the basis of the company's or individual's past and present qualitative and quantitative data (Yazıc1, 2009: 2). In other words, rating is a mathematical expression of the risk that you carry while you allocate credit to a company or individual (Tutar et al., 2011: 2)

Rating can be done for companies, enterprises, banks, financial organizations, local governments, fund demanders and suppliers, and countries. This situation, what we describe as country risk, arises due to the country's declaration of financial difficulties or present and future failure of certain countries to pay the debts they owe. A high country risk increases the cost of borrowing; namely, it causes an interest increase as well as complicating a country's borrowing. However, investors abstain from countries with high levels of country risk. Therefore, rating is defined as the probability of incurring losses in relations of lending in the international arena, as a result of significant events that may occur in countries where the credit is opened (Tutar et al., 2011: 2).

Nowadays, the large number of rating agencies has made pre-investment rating activities almost mandatory in financial markets. The number, and importance, of rating agencies has gradually increased with increasing capital flows among countries with the concept of liberalization and increasing financial diversity in financial markets in the 1980s. In the 1990s, the transformation of capital flows into private capital movements, instead of official funds provided by multinational organizations, has further increased the importance of rating agencies in global and local financial markets (Gür and Öztürk, 2011: 71). Due to these reasons, it is expected for the rating agencies to have a guiding role for investors in the future (Karagöl and Mihçıokur, 2012: 8).

However, in recent years, the unexpected bankruptcy of Lehman Brothers in the 2008 global financial crisis, the Enron incident, which occurred in 2001 before the 2008 crisis, Worldcom in 2002 and the Parmolat incident in 2003 have led to a questioning of the reliability of credit rating agencies. In 2008, a sudden lowering of the credit ratings of companies with a previously high credit rating was seen as an important factor in the exaggeration of the global crisis (Karagöl and Mıhçıokur, 2012: 9).

In this study the presence and direction of the relationship between the current account deficit and credit rating index for Turkey has been tested using GregoryHansen co-integration test, which considers structural breaks and Toda-Yamamoto causality analysis for the period of 1992-2014. 


\section{COUNTRY RISK (COUNTRY GREDIT RATING) AND CRITERIA OF RATING AGENCIES}

International rating agencies, such as Moody's, S\&P, and Fitch first started rating activities expressing a company's capacity to pay their debts and to meet the needs of investors. However, the development of financial markets contributed to the expansion of rating activities with the inclusion of the banks, insurance companies, local governments, and countries.

At first, while a country's economy wasn't taken into consideration (in case of running into debt), liberalization and development of international financing concepts in the 1980s have led to the need for addressing country's risks. Then, the country risk is an evaluation. In case of a company or an organization becoming indebted while assessing the payable capacity of its debt on time, country risk shows how the country's economic, political, and social circumstances effect paying debts what extend. Moreover, it is the possibility of the damage that can be incurred due to the issues that are considered to be under the control of the national government, even if it is a certain amount (Babuşcu, 1997: 39). Country risk is the highest degree that debtor companies can take in foreign currency because these companies do not have the ability to find more currency from the government or to convert the resources at hand.

The capacity of a country to pay its foreign debts is related to the company's foreign currency reserves. It is known that the payment of foreign debts on time is possible by closing the gap between import and export in long term, thereby increasing the country's net export. This predicts the consideration of the country's general economic structure, growth rate, and even political conditions. The country's credit worth is determined by indicators such as the country's foreign trade statistics, balance of payments, inflation rate, and debt coverage ratio. (Babuşcu, 1997: 40). Besides all these, there are subjective factors that could reveal the country's ability to repay its debts. In this case, determination of country risk is possible by a combination of social, economic, and political factors. Two types of uncertainty will be assessed at this point:

Political risk arises from the evaluation of the willingness of the countries during the payment of the foreign debts, as well as certain social and political issues that affect the payment capacity. Government policies, legal structure, and the country's position and importance in the international arena can be shown.

Economical risk is the most important factor that is considered when determining the economic risk of the countries. It is the income generation capacity of the country's economy. That is, the GNP (Gross National Product) rate of the country is the primary indicator. Change trend of GNP, investment allocations in GNP, and the ratio of public debt stock to GNP are the indicators to be considered. Another considered matter when determining the economic risk is foreign debt burden. This 
rate, which is called foreign debt service ratio, refers to the comparison of total annual foreign debt payments such as interest, capital installments, and dividend to the export income of that year (Babuşcu, 1997: 43). If this rate is high, it is described as the weakness of the country's debt repayment capacity. If a country with high foreign debt uses its debt for current expenditures, such as payment of debt or payment of interest instead of investment activities that increase GNP, it will reduce government spending activities as well as leading to an increase of country risk. A country's own resources, and the way it utilizes resources effectively, are the factors taken into consideration in identifying economic risk.

Five factors that form the basis of the country's credit rating, according to S\&P (www.satandardandpoors.com):

- Institutional effectiveness and political risks, reflected in the political lead.

- Economical structure and growth prospects, reflected in the economic score.

- External liquidity and international investment position, reflected in the external score.

- Financial performance and flexibility and government debt burden, reflected in the financial score

- Monetary flexibility, reflected in the monetary score

\subsection{Rating symbols of rating agencies and credit rating index}

Rating is a standard and objective view that helps to measure the creditworthiness of borrowers, debt repayment capacity, timely and orderly, and accordingly evaluates its role in money and capital markets formed by professionals (Yazici, 2009: 3). The following table shows the rating symbols of the three major rating agencies that perform professional rating activities at an international level as well as the credit rating index created by the symbols.

Table 1.: Rating symbols of rating agencies and credit rating index

\begin{tabular}{|c|c|c|c|c|}
\hline Moody's & $\begin{array}{l}\text { Standard \& } \\
\text { Poors }\end{array}$ & Fitch & $\begin{array}{l}\text { CREDIT } \\
\text { RATING } \\
\text { INDEX* }\end{array}$ & \\
\hline Aaa & AAA & AAA & 100 & Prime \\
\hline Aa1 & $\mathbf{A A}+$ & $\mathbf{A A}^{+}$ & 95 & High grade \\
\hline Aa2 & AA & AA & 90 & \\
\hline Aa3 & AA- & $\mathbf{A A}^{-}$ & 85 & \\
\hline Al & $\mathrm{A}^{+}$ & $\mathbf{A}^{+}$ & 80 & $\begin{array}{r}\text { Upper medium } \\
\text { grade }\end{array}$ \\
\hline $\mathbf{A}_{2}$ & A & A & 75 & \\
\hline A3 & $\mathbf{A}^{-}$ & $\mathrm{A}^{-}$ & 70 & \\
\hline Baaı & BBB + & BBB + & 65 & $\begin{array}{r}\text { Lower medium } \\
\text { grade }\end{array}$ \\
\hline
\end{tabular}




\begin{tabular}{|c|c|c|c|c|}
\hline Moody's & $\begin{array}{c}\text { Standard \& } \\
\text { Poors }\end{array}$ & Fitch & $\begin{array}{l}\text { CREDIT } \\
\text { RATING } \\
\text { INDEX }^{*}\end{array}$ & \\
\hline Baa2 & BBB & BBB & 60 & \multirow{5}{*}{$\begin{array}{l}\text { Non-Investment } \\
\text { grade speculative }\end{array}$} \\
\hline Baa3 & BBB- & BBB- & 55 & \\
\hline Baı & BB + & BB + & $5^{\circ}$ & \\
\hline Ba2 & BB & BB & 45 & \\
\hline Ba3 & BB- & BB- & 40 & \\
\hline B1 & B+ & B+ & 35 & \multirow[t]{3}{*}{$\begin{array}{r}\text { Highly } \\
\text { speculative }\end{array}$} \\
\hline $\mathrm{B}_{2}$ & B & B & $3 \circ$ & \\
\hline B3 & B- & B- & 25 & \\
\hline Caaı & CCC+ & CCC & 20 & Substantial risks \\
\hline Caa2 & CCG & $\mathrm{CC}$ & 15 & $\begin{array}{r}\text { Extremely } \\
\text { speculative }\end{array}$ \\
\hline Caa3 & CCC- & C & 10 & $\begin{array}{r}\text { In default with } \\
\text { little prospect for } \\
\text { recovery }\end{array}$ \\
\hline $\mathrm{Ca}$ & $\mathrm{CC}$ & CC & & \multirow{5}{*}{ In default } \\
\hline \multirow[t]{4}{*}{$\mathrm{C}$} & C & C & 5 & \\
\hline & D & DDD & o & \\
\hline & & DD & & \\
\hline & & $\mathrm{D}$ & & \\
\hline
\end{tabular}

Source: Prepared by benefiting from www.standardandpoors.com,

www.moodys.com and www.fitchratings.com, ${ }^{*} \mathrm{http}: / /$ www.tradingeconomics.com/turkey/rating

\section{TURKISH APPLICATION OF CREDIT RATING AGENCIES}

The relationship between Turkey and Credit Rating Agencies started in the 1990s. Turkey became a member of organizations such as the IMF, World Bank, GATT, and OECD after World War II in order to provide integration with the world. Further, it applied for full membership of the European Union in 1987. Table 2. shows the historical development of Turkey's credit rating. Turkey's credit rating was determined in 1992 as BBB by S\&P, Baa3 by Moody's and its credit rating index was 57.5 (lower medium). Turkey underwent an unstable period, both politically and economically, during the gos and this reflected in Turkey's credit rating. The gos and the early 2000s (1993-2002 period) can be defined economically by high inflation, high public debt, high budget deficit, resistless to external shocks and shortlived coalitions, and process and military tutelage was felt; therefore, it is extremely natural that Turkey's credit rating is low. Turkey's rating from three big credit agencies (S\&P, Moody's, and Fitch) from 1992 to 2002 has followed a downward trend 
with fluctuation. During this period, the credit rating index fell to the level of 26.67 by decreasing. Especially in 2001, economic contraction at a $9.5 \%$ ratio, high current account deficit, and devaluation caused Turkey's credit rating to bottom out. Between 2002 and 2008, Turkey's credit rating continued its upward trend as a result of economic and political stability. As a result of the 2008 global financial crisis, Turkey's economy contracted by $4 \cdot 7 \%$. This was reflected in Turkey's credit rating and lowered its rating temporarily. Turkey grew at high rates in 2010 and continued to grow in the following years. In 2012, it was promoted to an investable country position. As of 2014, Turkey's credit rating is S\&P: BB+ (Negative), Fitch: BBB- (Stable), and Moody's: Baa3 (Negative).

Table 2.: Historical development of Turkey's credit rating and credit rating index

\begin{tabular}{|c|c|c|c|c|}
\hline DATE & S\&P & MOOD'YS & FITCH & $\begin{array}{l}\text { TURKEY'S CREDIT } \\
\text { RATING INDEX* }\end{array}$ \\
\hline 04.05 .1992 & BBB (Stable) & & & \\
\hline 05.05 .1992 & & Ваa3 & & $57 \cdot 5$ \\
\hline 05.03 .1993 & BBB (Negative) & & & \\
\hline ०8.10.1993 & & Baa3 & & 55 \\
\hline 14.01.1994 & $\begin{array}{l}\text { BBB- } \\
\text { (Negative) }\end{array}$ & & & \\
\hline 02.06.1994 & & $\mathrm{Ba} 3$ & & 38.75 \\
\hline 10.06.1994 & & & B & \\
\hline 19.08 .1994 & B+ (Stable) & & & \\
\hline 24.07 .1995 & B+ (Positive) & & & 37.5 \\
\hline 26.09 .1995 & & & BB- & \\
\hline 17.07 .1996 & B- (Negative) & & & 30 \\
\hline 20.12 .1996 & & & $\mathrm{~B}+$ & \\
\hline 09.01.1997 & & $\mathrm{Ba} 3$ & & 40 \\
\hline $10.08 .199^{8}$ & B (Positive) & & & 35 \\
\hline 21.01.1999 & B (Stable) & & & 32 \\
\hline 30.11.1999 & & $\mathrm{B}_{1}$ (Positive) & & 32.5 \\
\hline 27.04 .2000 & & & BB- & \\
\hline 05.12 .2000 & $\mathrm{~B}+($ Stable $)$ & & & 36.67 \\
\hline 21.12 .2000 & & B1 (Positive) & & \\
\hline 04.06 .2001 & & B1 (Negative) & & \\
\hline 07.04 .2001 & B- (Stable) & & & 26.67 \\
\hline 02.08 .2001 & & & B (Negative) & \\
\hline 05.02 .2002 & & & B (Stable) & \\
\hline 09.07 .2002 & B- (Negative) & & & 26.67 \\
\hline 10.07 .2002 & & Bı (Negative) & & \\
\hline
\end{tabular}




\begin{tabular}{|c|c|c|c|c|}
\hline DATE & S\&P & MOOD'YS & FITCH & $\begin{array}{l}\text { TURKEY'S CREDIT } \\
\text { RATING INDEX* }\end{array}$ \\
\hline 28.07 .2003 & B (Stable) & & & \\
\hline 06.08 .2003 & & & B- (Positive) & \\
\hline $25.09 \cdot 2003$ & & & B (Positive) & 31.67 \\
\hline 16.10 .2003 & B+ (Stable) & & & \\
\hline 21.10 .2003 & & B1 (Stable) & & \\
\hline 09.02 .2004 & & & B + (Stable) & \\
\hline 08.03 .2004 & B + (Positive) & & & 3 \\
\hline 17.08 .2004 & BB - (Stable) & & & 5 \\
\hline 25.08 .2004 & & & B + (Positive) & \\
\hline 13.01 .2005 & & & BB - (Stable) & \\
\hline 11.02 .2005 & & B1 (Positive) & & 383 \\
\hline 06.12 .2005 & & & BB - (Positive) & \\
\hline 14.12 .2005 & & Ba3 (Stable) & & \\
\hline 23.01 .2006 & BB (Positive) & & & \\
\hline 27.06 .2006 & BB (Stable) & & & $47 \cdot 5$ \\
\hline 10.05 .2007 & & & BB - (Stable) & 40 \\
\hline 03.04 .2007 & BB - (Negative) & & & 40 \\
\hline $31.07 \cdot 2008$ & BB - (Positive) & & & \\
\hline 13.11.2008 & BB - (Negative) & & & 42.5 \\
\hline 17.09 .2009 & & Ba3 (Positive) & & \\
\hline 18.09 .2009 & BB - (Stable) & & & \\
\hline 27.10 .2009 & & & BB - (Positive) & 41.25 \\
\hline ○3.12.2009 & & & BB + (Stable) & \\
\hline 08.01 .2010 & & $\mathrm{Ba2}$ (Stable) & & \\
\hline 19.02 .2010 & BB (Positive) & & & 483 \\
\hline 05.10 .2010 & & $\mathrm{Ba2}$ (Positive) & & 40.0 \\
\hline 24.11 .2010 & & & BB + (Positive) & \\
\hline 23.11 .2011 & & & BB + (Stable) & 45 \\
\hline 01.05 .2012 & BB (Stable) & & & \\
\hline 20.06 .2012 & & Bar (Positive) & & $47 \cdot 5$ \\
\hline 27.03 .2013 & & & BBB- (Stable) & \\
\hline 28.04 .2013 & $\mathrm{BB}+($ Stable $)$ & & & $5^{3.3}$ \\
\hline 16.05 .2013 & & Baa3 (Stable) & & \\
\hline 02.07 .2014 & BB+ (Negative) & & & \\
\hline 11.04 .2014 & & Baa3 (Negative) & & $5^{3.3}$ \\
\hline $28.05 \cdot 2014$ & & & BBB- (Stable) & \\
\hline
\end{tabular}

Source: Prepared by benefiting from www.standardandpoors.com,

www.moodys.com, www.fitchratings.com, http://www.tradingeconomics.com/turkey/rating *

Credit Rating Index; has been calculated as the average of grades of S\&P, Moody's, and Fitch credit agencies. 
It is impossible to explain Turkey's credit rating as the same in 1992 and in 2014. Even the credit rating index in 2014 is lower than the credit rating index in 1992. It is observed that rating agencies violate the criteria of objectivity by not reflecting the major economic and political differences in the development of Turkey between 1992 and 2014, when determining the credit rating. Subjective applications being widespread decrease the trust in the credit rating agencies every day and also reduce the reputation of the grade changes of these agencies that follow the market subsequently and discriminate countries in grading.

It is useful to mention the main macroeconomic indicators of Turkey for the 1990-2014 period, which credit agencies consider. In 1990, GDP in Turkey was $\$ 15^{\circ}$ billion and income per capita was \$2790. In 2014 GDP in Turkey had increased by 5.5 times and reached $\$ 800$ billion, whilst income per capita increased by 3.9 times and reached $\$ 10,54,2$ billion. Especially after 2002, Turkey has grown an average of $4 \cdot 7 \%$. In this period, wherein such a high increase in production-growth was experienced, it is impossible to explain why Turkey's credit rating was not increased sufficiently with mere economic theory. While the ratio of public debt to national income was $10.8 \%$, it increased to $74.1 \%$ by rising steadily in 2001 . Then, in 2014 , it fell to $33 \%$ tending to decrease. When the criteria of the ratio of public debt to national income not exceeding 60\% is considered to be in Maastricht criteria, it is observed that the ratio of public debt to national income is very low in fast-growing Turkey.

When we look at the inflation rate, it is seen that the rate of inflation in Turkey is $60.3 \%$ in 1990. In 1994, inflation rose to the highest rate of $105 \%$ and in the later years it tended to decrease, especially after 2002 as a result of acceleration of the disinflation. In 2004, it dropped to single digits, and in 2013 it was $7 \cdot 5 \%$. It cannot be explained why the credit rating of Turkey with a 70\% inflation rate in 1992 and the credit rating of Turkey with a $8.9 \%$ inflation rate in 2014 are so close with mere economic theory.

In this period, when we look at the ratio of budget deficit to national income, it appears to be $2.2 \%$ in $1990,12.2 \%$ in 2001 , and $1.3 \%$ in 2014 . When the criteria of the ratio of budget deficit to national income does not to exceed $3 \%$, it is considered in Maastricht criteria; it is observed that this rate is very low in Turkey. Considering the unemployment rate, it appears to be $8.3 \%$ in $1990,14 \%$ in 2009, and 9.9\% in 2014. The rise in the unemployment rate in 2009 was caused by the reduction of Turkey's exports to the EU market due to the 2008 financial crisis. It should not be forgotten that EU countries' unemployment rates are in the double digits, higher than Turkey's unemployment rate.

Ignoring and not reflecting the economic developments between 1990 and 2014, which we explained above, in its credit rating means that Turkey has to meet its external financial needs with higher costs. It seems that the rating agencies claims that Turkey's current account deficit is high, and so it is fragile, indeed cause Turkey's current account deficit to increase by keeping Turkey's rating low. If Turkey's 
credit rating had been brought to the levels it deserves, Turkey's current account deficit would have been lower, since external borrowing costs (interest rate) would be lower. Despite this, fast-growing Turkey's current account deficit being at a reasonable rate is extremely normal.

Credit rating agencies are looking at political indicators alongside economic indicators when assessing countries. Turkey has seen economic and political stability in the last 12 years.

In recent years, when the political stability and macro-economic indicators are positive in Turkey credit rating agencies keep the country rating low on the grounds that the country's current account deficit being high. Not forgetting the fact that current account deficit being high lowering the credit rating, the fact that keeping the credit rating low increasing the current account deficit should not be ignored.

\subsection{Comparison of Turkey with countries with high credit ratings}

When we compare Turkey with some other countries that have higher credit note given by the three agencies, interesting results emerge.

Table 3.: Comparison of Turkey with some credit ratings and macro-economic indicators of member and non member states (2014)

\begin{tabular}{|c|c|c|c|c|c|c|c|c|c|c|}
\hline 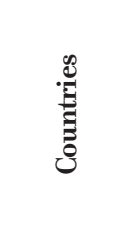 & & 预 & ${ }_{i}^{\infty}$ & 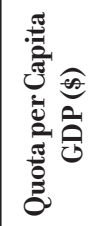 & 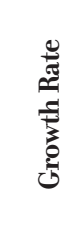 & 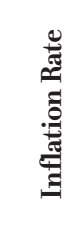 & 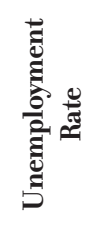 & 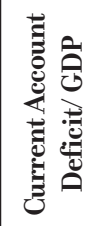 & 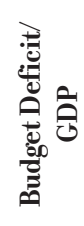 & 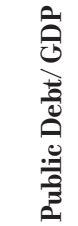 \\
\hline Turkey & $\mathrm{BB}+$ & BBB- & Baa3 & $1054^{2}$ & 2.86 & 8.9 & 9.9 & $-5 \cdot 7$ & -1.3 & 33 \\
\hline Spain & BBB & $\mathrm{BBB}+$ & Baa2 & $3 \circ 262$ & 1.38 & -0.1 & 2.7 & 0.8 & -5.8 & $97 \cdot 7$ \\
\hline Ireland & A- & $\mathrm{A}^{-}$ & Baı & $5^{3313}$ & 4.79 & 0.2 & 13.0 & 6.2 & -4.1 & $109 \cdot 7$ \\
\hline Italy & BBB- & $\mathrm{BBB}+$ & Baa2 & 34,960 & -0.42 & 0.2 & 12.2 & 1.9 & -3 & 132.1 \\
\hline Iceland & BBB- & BBB & Baa3 & $5^{2111}$ & 1.87 & 2.0 & $5 \cdot 2$ & 3.6 & -0.2 & 86.4 \\
\hline Lithuania & A- & $\mathrm{A}^{-}$ & Baar & 16037 & 2.36 & 0.6 & 11.2 & 0.1 & -0.7 & $4,0.9$ \\
\hline Mexico & BBB+ & BBB + & A3 & 10361 & 2.12 & 4.0 & 4.8 & -2.1 & -4 & 30.7 \\
\hline Romania & BBB- & BBB- & Baa3 & 9996 & 1.75 & 1.1 & $7 \cdot 4$ & -0.5 & -1.9 & 39.6 \\
\hline Slovak R. & A & $\mathrm{A}+$ & $\mathrm{A}_{1}$ & 18416 & 2.40 & -0.1 & 14.1 & 0.1 & -2.9 & $5^{3.6}$ \\
\hline Slovenia & A- & BBB+ & Bar & 23962 & 2.63 & 0.2 & 10.4 & 5.8 & -4.9 & 80.9 \\
\hline
\end{tabular}

Source: Prepared by benefiting from www.standardandpoors.com,

www.moodys.com, www.fitchratings.com, www.worldbank.org and www.oecd.org 
The credit rating of Spain, which is a member of EU, is better than Turkey, according to all three agencies. It is not possible to say the same thing about Spain's macroeconomic indicators. While Turkey's economy grew by $2.86 \%$, Spain's economy grew by only $1.38 \%$. Especially when considering that the unemployment rate, the ratio of budget deficit to national income, and ratio of public debt to national income are extremely poor. Turkey's unemployment rate is 9.9\%, but in Spain it is $26.7 \%$, Turkey's ratio of budget deficit to national income is 1.3\%, but in Spain it is $5.8 \%$, the ratio of public debt to national income is 33\% in Turkey, but in Spain it is $97 \cdot 7 \%$. Even these indicators show that Turkey's credit rating should be a few steps higher than that of Spain.

When we compare Turkey with Ireland: unemployment rate in Ireland is 13.०\%, ratio of budget deficit to national income is $4.1 \%$, and public debt to national income is $109 \cdot 7 \%$. Therefore, it is worse than Turkey. When we compare Turkey with Italy: the growth rate in Italy is $-0.42 \%$, the unemployment rate is $12.2 \%$, the ratio of budget deficit to national income is $3 \%$, and the ratio of public debt to national income is $132.1 \%$. It is also worse than Turkey.

In Mexico, which Moody's rates as A3, per capita income is $\$ 10361$, growth rate is $2.12 \%$, and the ratio of budget deficit to national income is $4 \%$. This country's macroeconomic indicators are worse than Turkey's too. In Romania, in which credit rating is higher than Turkey, per capita income is \$9499, growth rate is $3.5 \%$, the ratio of budget deficit to national income is $3 \%$, and public debt to national income is $37.1 \%$; Romania's data is worse than Turkey's data too.

In Slovakia, which three rating agencies gave grade $\mathrm{A}$, growth rate is $2.4 \%$, unemployment rate is $14.1 \%$, the ratio of budget deficit to national income is $2.9 \%$, and public debt to national income is $53.6 \%$. Its data is worse than Turkey's. Yet in Slovenia, which has an A grade, growth rate is 2.63\%, the unemployment rate is $10.4 \%$, the ratio of budget deficit to national income is $4.9 \%$, and public debt to national income is $80.9 \%$. Again, the data is worse than Turkey's.

As we have demonstrated in comparison above, while Turkey is better than other countries, in terms of many macro-economic indicators, its credit rating is being kept low only on the grounds of the high current account deficit. In this study, the relationship between the credit rating and the current account deficit, justified by credit rating agencies for Turkey to be a fragile country, is being investigated.

\section{DATA SET, ECONOMETRIC METHOD AND ANALYSIS}

\subsection{Data and methodology}

In this study, in order to determine the relationship between current account deficit and credit rating, the series comprised of annual data of current account deficit/GDP (CAD) for the period of 1992-2014 and credit rating index (IND) has been 
used. CAD data set was obtained from the World Bank statistics page. We designed the IND data set by utilizing the grades from Credit Rating Agencies (Table 2.). CAD and IND series used in the empirical analysis are presented in Figure 1.

Figure 1.: Course of variables

\section{CAD}

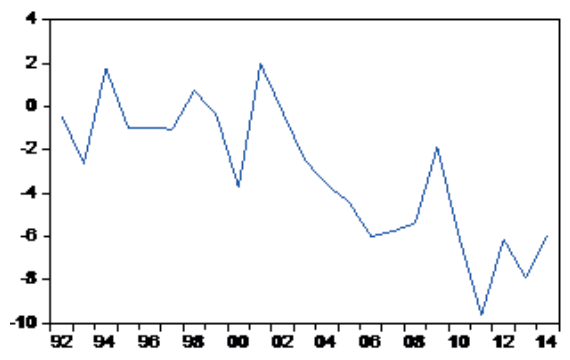

av

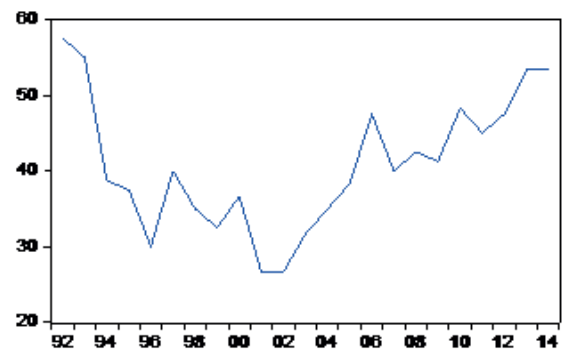

Source: Authors'

$\mathrm{CAD}$ and IND variables follow a fluctuating course for Turkey as of these years, as can be seen in figure 1 . By just looking at the chart we can say that CAD and IND variables have opposite movements.

\subsection{Econometric method}

In this part of the study, we present information about the Augmented Dickey Fuller (ADF) and Phillips Perron (PP) unit root test, which will be used in econometric analysis; Gregory-Hansen co-integration test will be provided and then TodaYamamoto causality test will be explained, and test results will be evaluated. Empirical results were obtained using EViews 9 econometric package program.

\subsubsection{ADF and pp unit root tests and results}

In time series analysis, in order to avoid erroneous results arising from especially spurious regression problems, it is important for the series to be stable. In this context, before application, the Augmented Dickey Fuller and Phillips Perron unit root tests and stability of the series has been analyzed.

In the $\mathrm{ADF}$ unit root test, in order to test if the $Y_{t}$ series contains unit root the following equation is used.

$$
\Delta Y_{t}=\alpha_{0}+\alpha_{1} t+\delta Y_{t-1}+\sum_{i=1}^{N} \psi \Delta Y_{t-i}+\varepsilon_{t}
$$

$\Delta$ represents the first difference processor, $t$ represents a time trend, $\varepsilon_{t}$ represents the error term, $Y_{t}$ represents the used series, $N$ represents delay number determined with Akaike Information Criterion. 
An alternative hypothesis that assumes the series as stable is tested with the ADF unit root test, in return the null hypothesis that is the series is not stable. The test is based on the estimation of $\delta$ parameter and determination of its test statistics. If the test statistics are greater than the critical values in absolute value, the null hypothesis is rejected. In other words, it can be said that the series is stable.

Another method used in stability analysis is the Phillips and Perron test. Phillips and Perron (PP) have criticized the ADF test, accepting the error terms are independent and with variance. In order for the ADF test to give meaningful results, correlation should not exist between error terms and it must be determined that the error terms have constant variance for certain. These two basic assumptions of the ADF test have been extended as follows by Phillips and Perron (Tarı, 2010: 399):

$$
\begin{aligned}
& Y_{t}=a_{0}+a_{1} y_{t-1}+u_{t} \\
& Y_{t}=a_{0}+y_{t-1}+a_{2}(t-T / 2)+u t
\end{aligned}
$$

$T$ shows number of observations and $\boldsymbol{u}_{\boldsymbol{t}}$ shows distribution of the error terms, and the expected value of the error terms is zero. Thus, the necessity of homogeneity assumption or absence of internal relations between error terms is eliminated by abandoning the homogeneity and independence assumptions of the ADF test (Tarı, 2010: 399). ADF and PP unit root test result are shown in Table 3..

\begin{tabular}{|c|c|c|c|c|}
\hline & \multicolumn{4}{|c|}{ LEVEL } \\
\hline & \multicolumn{2}{|c|}{ Constant } & \multicolumn{2}{|c|}{ Constant and Trend } \\
\hline & $\mathrm{ADF}$ & PP & $\mathrm{ADF}$ & $\mathrm{PP}$ \\
\hline CAD & $\begin{array}{l}-2.111 \\
\text { (o) }[0.2424]\end{array}$ & $\begin{array}{l}-1.934 \\
(2)[0.3116]\end{array}$ & $\begin{array}{l}-4.207^{* * *} \\
(0)[0.0161]\end{array}$ & $\begin{array}{l}-4.183^{* * *} \\
\text { (3) }[0.0170]\end{array}$ \\
\hline \multirow[t]{4}{*}{ IND } & $\begin{array}{l}-2.110 \\
\text { (o) }[0.2426]\end{array}$ & $\begin{array}{l}-2.164 \\
(2)[0.2239]\end{array}$ & $\begin{array}{l}-2.788 \\
\text { (o) }[0.2155]\end{array}$ & $\begin{array}{l}-2.887 \\
\text { (1) [0.1850] }\end{array}$ \\
\hline & \multicolumn{4}{|c|}{ FIRST DIFFERENCE } \\
\hline & \multicolumn{2}{|c|}{ Constant } & \multicolumn{2}{|c|}{ Constant and Trend } \\
\hline & $\mathrm{ADF}$ & PP & $\mathrm{ADF}$ & PP \\
\hline CAD & $\begin{array}{l}-5 \cdot 419^{* * * *} \\
\text { (1) }[0.0003]\end{array}$ & $\begin{array}{l}-12.883^{* * * *} \\
(20)[0.0000]\end{array}$ & $\begin{array}{l}-5.193^{* * * *} \\
\text { (1) }[0.0025]\end{array}$ & $\begin{array}{l}-15.03^{3 * * *} \\
(20)[0.0000]\end{array}$ \\
\hline IND & $\begin{array}{l}-5.224^{* * * *} \\
\text { (o) }[0.0004]\end{array}$ & $\begin{array}{l}-5.232^{* * * * *} \\
(1)[0.0004]\end{array}$ & $\begin{array}{l}-6.359^{* * * *} \\
\text { (o) }[0.0002]\end{array}$ & $\begin{array}{l}-6.358^{* * * * *} \\
\text { (o) }[0.0002]\end{array}$ \\
\hline
\end{tabular}

Table 4.: ADF and PP unit root analysis results

Source: Authors'

Notes: Proper length of delay in the ADF test is determined according to Schwarz information criteria. The PP test is determined according to "Barlet kernel" and bandwidth is determined according to "Newey West bandwith" method. Values in parentheses show optimum length of delay for the ADF test and bandwidth for the PP test. Numbers in square brackets show the probability ( $p$-value) values.

*** and ** shows 1 and 5 percent meaning levels respectively. 
According to Table 4., both variables comprise unit root in level status but it becomes stable when we take its first difference.

\subsubsection{Gregory-Hansen co-integration test and results}

After obtaining unit root test results the co-integration test, which was developed by Gregory and Hansen (1996), allows a single structural break to be applied. Gregory and Hansen Johansen developed the co-integration test to address the structural break as internally (Arısoy, 2013: 152).

In Gregory and Hansen co-integration test that allows structural break, the presence of long-term relationship between variables is tested using three different models. These are:

Model C (Refraction on Constant):

It is specified as:

$$
y_{1 t}=\mu_{1}+\mu_{2} \varphi_{t \tau}+\alpha^{T} y_{2 t}+e_{t} \quad t=1, \ldots, n \quad \text { (4) }
$$

In this model, $\mu_{1}$ shows the constant term and $\mu_{2}$ shows the change that is brought out by refraction in constant term.

Model C/T (Refraction on Constant with Trend):

It is specified as:

$$
y_{1 t}=\mu_{1}+\mu_{2} \varphi_{t \tau}+\beta t+\alpha^{T} y_{2 t}+e_{t} t=1, \ldots, n \quad \text { (5) }
$$

In this model, refractions in both constant term and trend are considered.

Model C/S (Regime Change):

It is specified as:

$$
y_{1 t}=\mu_{1}+\mu_{2} \varphi_{t \tau}+\alpha_{1}^{T} y_{2 t}+\alpha_{2}^{T} y_{2 t} \varphi_{t \tau}+e_{t} \quad t=1, \ldots, n
$$

It is as stated in the model that shows refraction on constant. $\alpha_{1}$ shows slope coefficient before refraction, $\alpha_{2}$ shows the changes occurring after refraction (Gregory and Hansen, 1996: 103).

Structural refraction can be identified by puppet variables, mentioned below for three models:

$$
\varphi_{1 t}=\left\{\begin{array}{lll}
0, & \text { if } & t \leq[n \tau] \\
1, & \text { if } & t \succ[n \tau]
\end{array}\right.
$$

Here $\tau$ expresses the structural refraction point with $(0,1)$ values, $[n \tau] \mathrm{ex}^{-}$ presses the integer part of the structural refraction point (Gregory and Hansen, 1996: 102). 
The minimum date for the Philips test statistics calculated for these three models $\left(Z_{\alpha}^{*}\right.$ and $\left.Z_{t}^{*}\right)$ and Augmented Dickey Fuller test statistic $\left(A D F^{*}\right)$ is the suitable refraction date for co-integration test. Test statistics are:

$$
\begin{aligned}
& Z_{\alpha}^{*}=\inf Z_{\alpha}(\tau) \\
& Z_{t}^{*}=\inf Z_{t}(\tau) \quad \tau \in T \\
& A D F^{*}=\inf A D F(\tau)
\end{aligned}
$$

(Gregory and Hansen, 1996: 106).

Test statistics determined for a proper model are compared with the table critical values and the alternative hypothesis, which shows there is a co-integration relationship between the variables with a structural refraction, is tested against the basic hypothesis of there being no co-integration between variables. Table critical values, determined by the number of variables, are located in the study of Gregory and Hansen (1996) (Tıraşoğlu and Yıldırım, 2012: 115).

In order to find out whether there is a long-term relationship between the variables under the structural refraction (because the both series are I (1)), after determining the stability levels of the series, the Gregory-Hansen co-integration test was conducted. The minimum ADF test statistics and their corresponding refraction periods are shown in Table 5 .

Table 5.: Gregory-Hansen co-integration test results

\begin{tabular}{|l|l|l|lc|}
\hline \multicolumn{1}{|c|}{ Model } & \multicolumn{1}{|c|}{ Refraction Period } & \multicolumn{1}{|c|}{ ADF Statistics } & \multicolumn{2}{c|}{$\begin{array}{c}\text { Critical Values } \\
\mathbf{\% 1} \% \mathbf{5}\end{array}$} \\
\hline Model C & 2003 & $-5.41^{* * *}(0)$ & -5.13 & -4.61 \\
Model C/T & 1993 & $-5.04^{* *}(0)$ & -5.45 & -4.99 \\
Model C/S & 2003 & $-5.48^{* * *}(1)$ & -5.47 & -4.95 \\
\hline
\end{tabular}

Source: Authors'

Note: Critical values were taken from Gregory and Hansen (1996: 109). Values in parentheses indicate the delay number selected by Akaike Information Criteria.

Because the minimum ADF statistic calculated for the models is greater ( $1 \%$ for Model C and Model C/S, 5\% for Model C/T at meaning level) than critical values as absolute value, the basic hypothesis shows there is no co-integration relationship between series and cannot be accepted. Hence, according to the Gregory-Hansen test results, it is possible to say that there is a long-term relationship between current account deficit and credit rating index. Also, there is a structural refraction in 1994 for the three models. When compared with the previous years, year 1994 in Turkey is the highest year in inflation, public deficit, and current account deficit. 1994, is a year in which the inflation rate rose 
to $105 \%$, public and private sector borrowing interest rate rose to three-digit numbers, and with a $50 \%$ real interest rate, the government could not find any debt, even short-term debt. Economic crisis affecting Turkey deeply emerged in 1994. At the end of the crisis (April 5 1994), decisions and policies had begun to apply to prevent the crisis.

\subsubsection{Toda-Yamamoto causality test and results}

Toda and Yamamoto (1995) have developed a test whereby the causality relationship between the series can be observed without the need for prior knowledge of stability and co-integration.

For the Toda and Yamamoto test, primarily proper delay level ( $p$ ) in the VAR model is determined. Then, the maximum integration degree $\left(d_{\max }\right)$ is added to $p$ delay. In the next step, the original values of the series and the EKK model is estimated for the $d_{\max }$ delay (Büyükakın et al., 2009: 111). The VAR $\left(\mathrm{p}+\mathrm{d}_{\max }\right)$ model used in Toda and Yamamoto test is identified as follows (Toda and Yamamoto, 1995: 230):

$$
\begin{aligned}
& Y_{t}=\alpha_{0}+\sum_{i=1}^{p+d_{\max }} \alpha_{1(i+d)} Y_{t-(i+d)}+\sum_{i=1}^{p+d_{\max }} \alpha_{2(i+d)} X_{t-(i+d)}+\varepsilon_{1 t} \\
& X_{t}=\beta_{0}+\sum_{i=1}^{p+d_{\max }} \beta_{1(i+d)} Y_{t-(i+d)}+\sum_{i=1}^{p+d_{\max }} \beta_{2(i+d)} X_{t-(i+d)}+\varepsilon_{2 t}
\end{aligned}
$$

Finally, constraint is put on the variables respectively and for the $p$ delay, the significance of these constraints is tested by applying a standard Wald test (Büyükakınet al., 2009: 111). For example, if the basic hypothesis is accepted for the first equation, the result will be that there is no causal relationship from X to Y. Other causal relationships are tested in a similar way.

In this part of the study, existence and direction of the causal relationship between current account deficit and credit rating index will be analyzed using a Granger causality test, which is Toda-Yamamoto based.

Table 6.: Results of Toda-Yamamoto causality test

\begin{tabular}{|l|l|r|}
\hline \multicolumn{1}{|c|}{ Basic Hypotheses } & Delay Length & $\chi^{2}$ Statistic \\
\hline IND CAD & $(\mathrm{p}=1)+\left(\mathrm{d}_{\max }=1\right)=2$ & $0.861300(0.6501)$ \\
CAD IND & $(\mathrm{p}=1)+\left(\mathrm{d}_{\max }=1\right)=2$ & $12.99714(0.0015)$ \\
\hline
\end{tabular}

Source: Authors'

Note: Values in parentheses are probability values of the related test statistic. P value for the proper VAR model was determined according to Schwarz Information Criterion. 
As can be seen in Table 6., while the hypothesis that shows that the credit rating index is not the Granger reason for current account deficit is accepted ( 0.6501 ), the basic hypothesis that shows current account deficit is not the Granger reason for credit rating index is rejected $(0.0015)$. Therefore, according to Toda-Yamamoto causality analysis results, there is a one-way causal relationship between variables, and the direction of the relationship is from current account deficit to credit rating index. Changes in credit rating index have a power to be explained by past values of the current account deficit variable. In brief, while the credit rating index is affected by the current account deficit, credit rating index has no effect on current account deficit.

\section{CONCLUSION}

In this study, the relationship between current account deficit and credit rating index has been examined. While analyzing this relationship, a structural refracting cointegration test has been used in order to observe the seasonal effects that Turkey has faced. At the end of the unit root tests, it was determined that the series contain unit roots at their level values and, when the first differences of the series are taken, it is observed that they have become stable. Since both series are stable from the first order, existence of a long-term relationship between variables has been tested with the co-integration test and it was concluded that there is a long-term relationship between variables.

A causality test has been applied in order to determine whether past values of one of the variables has a power to explain the change in the other variable as well as the direction of this relationship. It has been obtained that there is a one-way causal relationship between variables from current account deficit to credit rating index. International credit rating agencies, as a justification for Turkey's low credit rating, emphasize that the current account deficit in Turkey is high and, therefore, the Turkish economy is fragile. In this context, it is expected for a negative relationship to come out between current account deficit and credit rating. However, as can be seen from the econometric examination done here, it is observed that there is no relationship between current account deficit and credit rating. This situation can be interpreted as the especially highlighted current account deficit situation not effecting low ratings, indeed, and credit ratings given based on subjective ratings. For example, in 2014, although Turkey's current account deficit has shown a serious fall, international credit rating agencies haven't made any changes in Turkey's credit rating.

The credit rating of Turkey, which is in low development effort (shown low), causes the country to find external sources with higher costs and development efforts to slow down. Gredit rating agencies should provide guidance to investors. However, they slow down some countries' developments with their grades (as in Turkey) and this causes decreasing trust in such institutions. Therefore, credit rating agencies to be effective in global terms; they need to observe objectivity, transparency, and neutrality principles when giving grades to countries. 


\section{REFERENCES}

Arssoy, I.., "Testing for the Relationship Between Industrial Sector and Economic Growth in the Context of Kaldor Hypothesis: The Case for Turkey", Eskişehir Osmangazi Üniversitesi İIBF Dergisi 8 (1), (2013): $143-162$

Babuşçu, Ş. 1997. "Bankacllıkta Risk Değerlendirmesi ve Türk Bankacıllk Sektörüne Uygulanması.", Sermaye Piyasası Kurulu, Ankara.

Büyükakın, F., Bozkurt H. and Cengiz V., "Analysis Of The Interest Rate Channel Of Monetary Transmission With Granger Causality And Toda Yamamoto Method In Turkey", Erciyes Üniversitesi İktisadi ve İdari Bilimler Fakültesi Dergisi 33, (2009): 101-118

Gregory, A.W. and Hansen B.E., "Residual-based tests for cointegration in models with regime shifts.", Journal of Econometrics 7o (1), (1996): 99-126

Gür, T.H. and Öztürk H., "Country Risk, Rating Agencies, Problems and New Arrangements.", Sosyo Ekonomi Temmuz-Aralık: (2011): 70-92

http://data.worldbank.org/indicator (Accessed: 24.10.2015)

http://stats.oecd.org/ (Accessed: 24.10.2015)

http://www.standardandpoors.com/spf/upload/Ratings_EMEA/2012-o3- o1_

UlkerlerinKrediNotunuBasilBelirliyoruz.pdf

http://www.tradingeconomics.com/turkey/rating (Accessed: 24.10.2015)

Karagöl, E. T. and Mıhçıokur Ü. İ. 2012. "Kredi Derecelendirme Kuruluşları: Alternatif Arayışlar.", SETA Rapor

Moody's Investors Service, "Moody's Rating System in Brief", www.moodys.com, (Accessed: 24.10.2015)

Moody's Investors Service, (2012), "Rating Symbols and Definitions", www.moodys.com, (Accessed: 24.10.2015)

Tarı, R. 2010. "Ekonometri.”, Genişletilmiş 6. Baskı, Kocaeli: Umuttepe Yayınları

Tıraşoğlu, M. and Yıldırım B., "Health Expenditure and Economic Growth Relationship In The Case Of Structural Break: A Case Study For Turkey", Electronic Journal of Vocational Colleges 2(2), (2012): 111-117

Toda, H.Y. and Yamamoto T., "Statistical Inference In Vector Autoregressions With Possibly Integrated Processes.", Journal of Econometrics 66(1-2), (1995): 225-250

Tutar, E., Tutar F. and Eren M.V., "The Roles Of International Credit Rating Agencies, Questioning About Their Reliability And Turkey.", Akademik Bakş̧ Dergisi, 25, (2011): 1-24

Yazıcı, M. 2009. "Kredi Derecelendirme Kuruluşlarının Önemi ve Denetimi.", Maliye ve Finans Yazıları Hakemli Dergisi. 